\title{
5: 65258140-65412100
}

National Cancer Institute

\section{Source}

National Cancer Institute. 5: 65258140-65412100. NCI Thesaurus. Code C42204.

Physical location of ERBB2IP_Gene 